\title{
Development of a water recirculating system for bullfrog production: technological innovation for small farmers
}

\section{Desenvolvimento de um sistema de recirculação de água para produção de rã-touro: inovação tecnológica para o pequeno produtor}

\author{
Sílvia Conceição Reis Pereira Mello ${ }^{1,2^{*}}$, Roberto Rodrigues de Oliveira ${ }^{3}$, Marcelo Maia Pereira ${ }^{1}$, \\ Eliane Rodrigues ${ }^{4}$, Willian Nascimento Silva ${ }^{1}$, José Teixeira de Seixas Filho ${ }^{1,2}$
}

\author{
${ }^{1}$ Fundação Instituto de Pesca do Estado do Rio de Janeiro/FIPERJ, Rio de Janeiro, RJ, Brasil \\ ${ }^{2}$ Centro Universitário Augusto Motta/UNISUAM, Rio de Janeiro, RJ, Brasil \\ ${ }^{3}$ Centro Federal de Educação Tecnológica Celso Suckow da Fonseca/CEFET, Rio de Janeiro, RJ, Brasil \\ ${ }^{4}$ Empresa de Pesquisa Agropecuária do Estado do Rio de Janeiro/PESAGRO, Niterói, RJ, Brasil \\ *Corresponding author: silviaqua@uol.com.br \\ Received in august 4, 2015 and approved in october 16, 2015
}

\begin{abstract}
Despite the technological progress in frog farming, issues related to the environment, biosafety, and the use of technologies that minimise environmental impacts are frequently neglected by farmers. With the goal of developing a low-cost technology for reuse and preservation of water quality, an anaerobic filtering system combined with an aerobic filtering system was implemented in the grow-out sector in the Frog Culture Research Unit at Fundação Instituto de Pesca do Estado do Rio de Janeiro (FIPERJ). The filtering system received the effluent from six pens of frogs that were populated with 362 frogs in different development phases. The efficiency of the filtering system was evaluated by an analysis of the water before and after passing through the filters. In addition to the standards of water quality, the animals' performance was also observed through monitoring rates of survival, weight gain and feed conversion ratio. The results showed the effectiveness of the filtering system by removing organic matter, on average $87 \%$. The values of total ammonia and non-ionisable reached 1.04 and $0.004 \mathrm{mg} / \mathrm{L}$, respectively. Also, frogs subjected to the system presented satisfactory rates of weight gain and a high survival rate (97\%).
\end{abstract}

Index terms: Frog farming; effluent treatment; environmental preservation; local development.

\begin{abstract}
RESUMO
Apesar da evolução tecnológica da ranicultura, ainda é possível perceber que as questões voltadas para o meio ambiente, biossegurança e emprego de tecnologias que reduzam o impacto ambiental, são frequentemente ignoradas pelos criadores. Com o objetivo de desenvolver uma tecnologia de baixo custo para reuso e preservação da água foi implantado um sistema de filtragem anaeróbia, acoplado à filtragem aeróbia, no setor de engorda inundado do ranário experimental da Fundação Instituto de Pesca do Rio de Janeiro (FIPERJ). O sistema de filtragem recebeu o efluente de seis baias de engorda. A eficiência do sistema foi avaliada, por meio da análise da água antes e depois da passagem nos filtros. Além dos padrões de qualidade da água foi observado o desempenho dos animais, por meio das taxas de sobrevivência, ganho de peso e conversão alimentar. Os resultados obtidos evidenciaram a eficiência do sistema, em média foram removidos $87 \%$ da matéria orgânica. Os valores médios de amônia total e amônia não ionizável, após a filtragem aeróbia, foram respectivamente 1.04 e $0.004 \mathrm{mg} / \mathrm{L}$. Conclui-se, ainda, que as rãs submetidas ao sistema apresentaram taxas satisfatórias de ganho de peso, conversão alimentar e sobrevivência (97\%).
\end{abstract}

Termos para indexação: Ranicultura; tratamento de efluente; preservação do ambiente; desenvolvimento local.

\section{INTRODUCTION}

The bullfrog (Lithobates catesbeianus) is the most reared species worldwide and has adapted very well to Brazilian climatic conditions. Other species are also studied in Brazil for commercial purposes, but did not show good production performance (Carraro, 2008).

Frog culture is an activity in expansion, with technological consolidation in several countries, particularly in Brazil, China, Ecuador, Indonesia, Mexico,
Taiwan and Thailand. The basic rearing technique involved confinement, intensive feeding, strict hygiene practices and close supervision (Teixeira; Mello; Lima, 2001).

The wet or inundated system was first employed in Asia, mostly in Taiwan and Thailand, and later adapted in Latin America in Argentina, Uruguay, Ecuador, Guatemala, and Mexico. Pens are made of a wide variety of materials, such as plastic-lined wooden frames or plastic-lined cinderblock. Culture pens of the wet type, as 
opposed to those in semi-dry systems, can be employed for either of the frog culture phases (i.e., tadpole rearing nursery or grow-out sector). Each pen has its own water inlet and drainpipe, and a constant flow of water is kept throughout the culture period (Flores-Nava, 2000).

The bullfrog farming system shows high nitrogen and phosphorus concentrations coming from the excessive food and excreta of animals and according to the current legislation, this system is irregular with respect to the discharge of effluent with high nutrients concentrations, a potential inducer of the eutrophication process (Mercante et al., 2014).

Among the ways to treat effluents, there are some that are very complex with a high-cost of deployment and operation, and others are simpler. The implementation of these treatments depends on several factors such as available area and volume of effluents, among others.

The water recirculating system is successfully used in aquaculture from developed countries, but in most cases the equipment used is high-tech and high-cost, far from the reality of small frog farmers in developing countries.

This study aimed to deploy and evaluate the use of an anaerobic biofilter coupled to an aerobic biofilter in the treatment and reuse of water from the grow-out sector at the Frog Culture Research Unit of FIPERJ in Guaratiba, Rio de Janeiro. This would thus enable the reuse of the water through a low deployment cost filtration system, avoiding wastes and the release of organic waste in receiving bodies, and contributing greatly to controlling the escape of individuals to the environment through water drainage from the frog pens.

\section{MATERIAL AND METHODS}

\section{Facilities of the grow-out sector of frogs and of the water filtration system}

This study was developed at the Frog Culture Research Unit of FIPERJ in Guaratiba, geographic coordinates S $22^{\circ} 59^{\prime} 57.2^{\prime \prime}$ and W $043^{\circ} 35^{\prime} 22.4^{\prime \prime}$, in the city of Rio de Janeiro from July to September 2011. The proposal was to simulate a small breeding frog farm. The shed for growing and fattening of frogs has a useful area of $150 \mathrm{~m}^{2}$, with $1 \mathrm{~m}$-high side walls. Inside the shed, six circular pens are arranged. Each has $6.6 \mathrm{~m}^{2}$ of floor area, and $1 / 4$ of the pens have an elevated floor that remained dry. The water level of the pens was kept by controlling the height of the drainage pipes with a $100-\mathrm{mm}$ diameter, and protected with a $4-\mathrm{mm}$ mesh screen placed inside each pen. The water depth was kept between three and five centimetres, according to the average size of the lot, so that the head of the animals remained out of the water.

The pens were individually supplied with water through $3 / 4$ inch PVC pipes, coupled to taps. In each tank, the tap was adjusted to maintain a constant water flow for 24 hours. The water supply was from the aerobic and anaerobic biological filtration system, i.e., water passed through filters, first by the anaerobic biofilter, then by the aerobic biofilter. The mean volume of water stored in each pen was 280 litres, totaling 1,680 litres; in this way, every 24 hours approximately $200 \%$ water volume was recirculated. Once a week 5\% (250 litres) of aerobic biofilter water volume was replaced, to cover the losses incurred during the handling of frogs.

The aerobic biofilter has a storage capacity of $5 \mathrm{~m}^{3}$ and was partially filled with three filtering element layers, gravel \# zero $(10 \mathrm{~cm})$, dolomite $(5 \mathrm{~cm})$, and beach gravel $(5 \mathrm{~cm})$.

The construction of the anaerobic biofilter followed the recommendations of Cynamom (1986) and legislation adopted in the State of Rio de Janeiro and Brazil: Guideline for Control of Biodegradable Organic Load in Wastewater from Sanitary Source, DZ-215. R-4 (Instituto Estadual do Ambiente-Inea, 2007) and rules of the Brazilian Association of Technical Standards, NBR 13.969 (Associação Brasileira de Normas Técnicas-Abnt, 1997) and NBR 7229 (Abnt, 1993).

In the construction of the anaerobic biofilter, rectangular filter rings were used, molded in situ with reinforced concrete. In order to avoid contact between the effluent to be treated and the groundwater, we adopted a section of $0.50 \mathrm{~m} \times 0.50 \mathrm{~m}$ to build the filter chambers that met the scaling criterion used, both for the application rate of organic load and hydraulic load.

In dimensioning the biofilter, the application rate of the hydraulic load was set from 10 to $20 \mathrm{~m}^{3} / \mathrm{m}^{2}$ per day, and organic loading between 1 and $2 \mathrm{Kg} / \mathrm{m}^{3}$ per day. The flow rate was measured in situ, using a graduated container with three successive repetitions, thus calculating the arithmetic mean. The daily flow rate was $4.32 \mathrm{~m}^{3} /$ day in the six pens. The organic load value $\left(0.47 \mathrm{~kg} / \mathrm{m}^{3} /\right.$ day $)$ was obtained by multiplying the flow by the biochemical oxygen demand obtained by laboratory analysis.

The operational and maintenance facilities were also considered the ease of construction, installation and operation of the system.

The anaerobic treatment system was divided into six types of compartments (Figure 1): 1) inspection boxes connected to each of the six pens for growing and fattening of frogs; 2) solid separation box, which received the wastewater from the six pens where only the liquid phase, with suspended solids, passed to the septic tank; 3) septic 
tank that started the organic matter digestion; 4) anaerobic biofilter divided into three chambers, filled with gravel \# 4 (support medium for bacteria); the flow descended in the first chamber, ascended in the second, and descended in the third chamber; the use of three chambers enlarges the contact surface of substrate with bacteria; 5) final polishing chamber that received the effluent and ended the anaerobic filtration; 6) collector box that received the previously treated effluent and pumped it to the aerobic biofilter.

\section{Pre-experimental period: stabilising the anaerobic biofilter}

During this period, daily values of water $\mathrm{pH}$, temperature, total ammonia and toxic ammonia $\left(\mathrm{NH}_{3}\right)$ were measured by colorimetry in three sampling points: central collector box, anaerobic biofilter outlet, and aerobic biofilter outlet, using a kit for controlling water quality in aquaria $\left(\mathrm{LABTEST}^{\circledR}\right)$. The temperature was measured with a digital thermometer.
After constructing the anaerobic biofilter, the system was subjected to 37 observational days to allow its stabilisation. The filter stabilisation was required for anaerobic bacteria to form a film capable of retaining the excess of organic load from the water During this period, daily values of water $\mathrm{pH}$, temperature, total ammonia and toxic ammonia $\left(\mathrm{NH}_{3}\right)$ were measured by colorimetry in three sampling points: central collector box, anaerobic biofilter outlet, and aerobic biofilter outlet, using a kit for controlling water quality in aquaria $\left(\mathrm{LABTEST}^{\circledR}\right)$. The temperature was measured with a digital thermometer.

During the stabilisation period, growing and fattening pens were populated with frogs divided into groups according to live weight totaling 396 frogs stocked during the acclimation period, making a total biomass of $76.25 \mathrm{~kg}$. For each kilo of live frog were produced every day nine grams of fresh solid waste, in this way approximately 686 grams of solid waste/day was produced during the period of the anaerobic filter stabilisation.

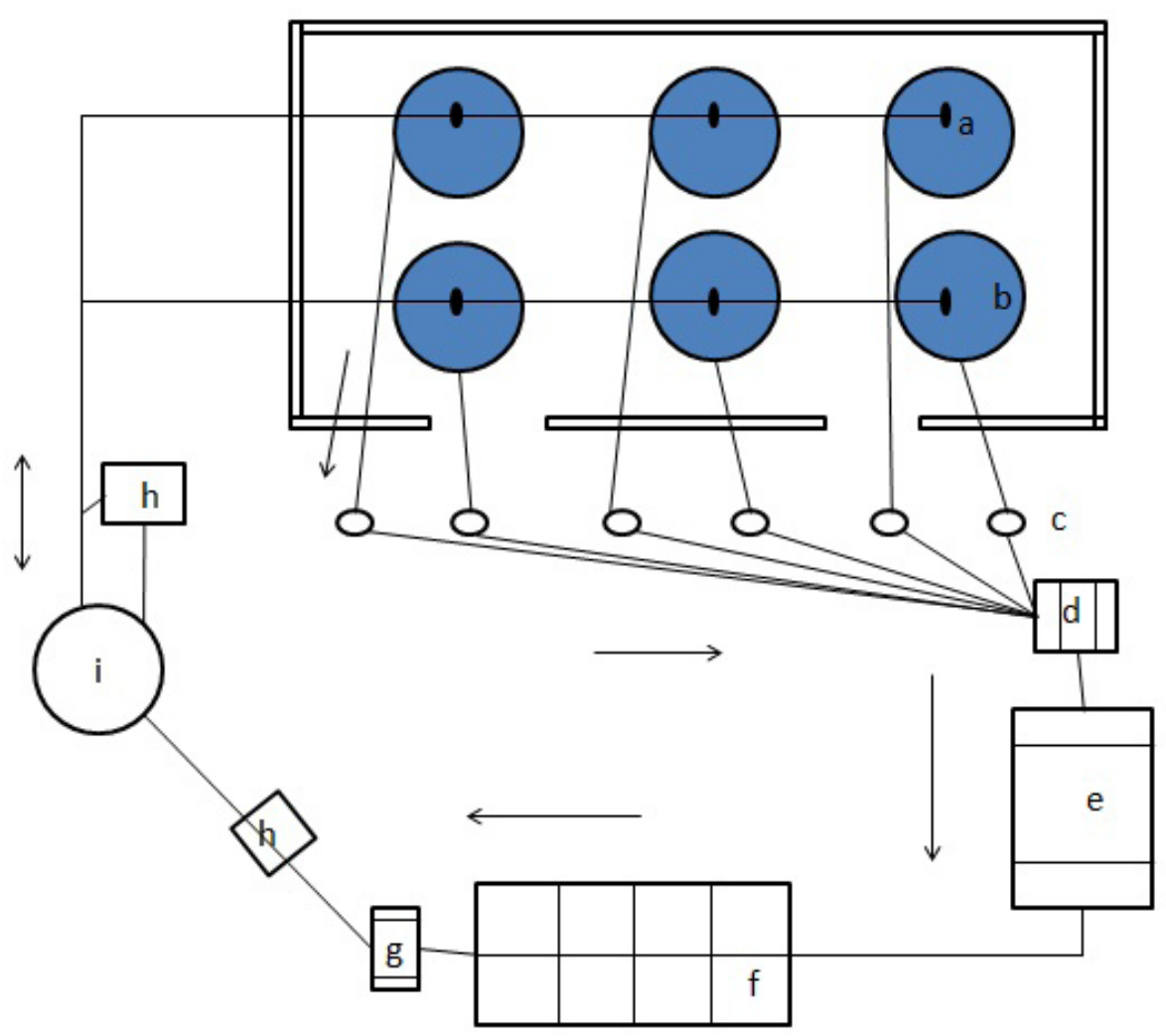

Figure 1: Recirculating system for producing frogs. The units are: (a) water supply, (b) frog culture pen, (c) inspection box, (d) solid separation box, (e) septic tank, ( $f$ ) anaerobic biofilter divided into three chambers and one final polishing chamber, (g) water storage box, (h) pump, (i) aerobic biofilter. 
Feed was supplied twice a day, at 10:00 and at 15:00. The amount varied based on the biomass of each pen, and a commercial extruded feed for carnivorous fish was used.

During the pre-experimental and experimental period, the frogs were fed twice a day and the amount varied based on the biomass of each pen. A commercial extruded diet developed for tropical carnivorous freshwater fish was used. Assurance levels: $13.00 \%$ moisture; $40.00 \%$ crude protein; $10.00 \%$ ether extract; $9.81 \%$ crude fibre; $13.00 \%$ ash; $2.50 \%$ calcium; $1.00 \%$ phosphorus. Analysed composition: $9.54 \%$ moisture; $41.85 \%$ crude protein; $6.79 \%$ ether extract; $6.00 \%$ crude fibre; $9.81 \%$ ash; $2.50 \%$ calcium; $1.00 \%$ phosphorus; 4501 crude energy $\left(\mathrm{kcal} \mathrm{kg}^{-1}\right)$. Basic diet composition: soybean meal, fishmeal, wheat bran, corn gluten meal $60 \%$, meat and bone flour, corn, blood meal, fish oil, calcium carbonate, dicalcium phosphate. Salt vitamin supplement (1), salt mineral supplement (2), antioxidant (3). (1) Composition per kg: vitamin A, $12.000 \mathrm{UI}$; vitamin D3, 4.000 UI; vitamin E, 150 UI; vitamin K, 10 UI; Folic Acid, $10 \mathrm{mg}$; biotin, $0,8 \mathrm{mg}$; coline, $500 \mathrm{mg}$; niacin, $150 \mathrm{mg}$; calcium pantothenate, $50 \mathrm{mg}$; thiamine, $30 \mathrm{mg}$; riboflavin, $30 \mathrm{mg}$; pyridoxine B6, $30 \mathrm{mg}$; vitamin B12, $35 \mu \mathrm{g}$; vitamin C, 300 mg. (2) Composition per kg: Mg, 700 mg; Mn, 30 mg; Zn, 200 mg; Cu, 15 mg; Fe, 100 mg; I, 1 mg; Se, 0.3 mg. (3) Ethoxyquin, $250 \mathrm{mg}$.

\section{Distribution and management of frogs in growing and fattening pens during the experimental period}

After the filter stabilisation period, a new biometry was carried out for the onset of monitoring the performance of animals submitted to rearing in a water recirculating system; the monitoring lasted 40 days. Frogs were pooled in the pens according to the size range. Twenty animals of each pen were then individually weighed, and an estimation was made of the biomass of each pen as well as the load of solid waste produced. The weighing procedure consisted primarily of the container tare on a balance with a capacity of $2 \mathrm{~kg}$ accuracy to $0.01 \mathrm{~g}$. Then in the accommodation and weighing of the frog in an appropriate container to prevent its escape, the average weight per pen varied between 65 and 311 grams. The interval between biometry measurements was 20 days.

In Table 1 data are shown from the beginning of monitoring the animals' performance relative to the number of animals per pen total weight of animals, the amount of feed supplied each day, and the estimation of fresh and dry solid waste produced every day.

During the experimental period, daily values of water $\mathrm{pH}$, temperature, total ammonia and toxic ammonia $\left(\mathrm{NH}_{3}\right)$ were measured in three sampling points: central collector box, anaerobic biofilter outlet, and aerobic biofilter outlet. The levels were determined by colorimetry, and a kit for controlling the water quality in aquaria (LABTEST $^{\circledR}$ ) was used. The temperature was measured with a digital thermometer.

The values of BOD and total phosphorus, were obtained from samples collected in triplicate at the central collector box, anaerobic biofilter outlet, and aerobic biofilter outlet. The samples were collected on the first, twentieth and fortieth days during the experimental period, then were sent to a laboratory accredited by the State Environmental Institute of Rio de Janeiro (INEA-RJ). The methodology used for phosphorus determination was based on the Association of Official Analytical Chemists (Association Of Official Analytical Chemists-Aoac, 1990) and for BOD determination, the BOD test was used in five days (Inea, 2007).

Table 1: Number of frogs, total weight of the lot, daily amount of feed supplied, and estimate of fresh and dry solid waste produced every day at the beginning of the experimental period.

\begin{tabular}{cccccc}
\hline Pens & $\begin{array}{c}\text { Number of } \\
\text { frogs }\end{array}$ & $\begin{array}{c}\text { Total weight of } \\
\text { the lot (g) }\end{array}$ & $\begin{array}{c}\text { Amount of feed/ } \\
\text { day(g) }\end{array}$ & $\begin{array}{c}\text { Estimate of fresh solid } \\
\text { waste (g/day) }\end{array}$ & $\begin{array}{c}\text { Estimate of dry solid } \\
\text { waste (g/day) }\end{array}$ \\
\hline 1 & 74 & 23.031 & 345.5 & 207 & 57.6 \\
2 & 60 & 12.989 & 195 & 117 & 32.4 \\
3 & 90 & 21.991 & 330.5 & 198 & 55 \\
4 & 52 & 17.466 & 262 & 157 & 44 \\
5 & 59 & 3.891 & 78 & 35 & 9.8 \\
6 & 27 & 2.993 & 20 & 27 & 7.5 \\
\hline GRAND TOTAL & 362 & 82.361 & 1.231 & 741 & 206.3 \\
\hline
\end{tabular}




\section{Statistical analyses}

For the analysis of physical and chemical water variables obtained daily at the different sampling points, an analysis of variance (ANOVA) was run, and to compare the means, a t-test was performed using the software XLSTAT.

The results of Biochemical Oxygen Demand (BOD) and phosphorus of the different sampling points were analysed by a Friedman test and software R. To compare the means, a Wilcoxon test was adopted using the software XLSTAT.

\section{RESULTS AND DISCUSSION}

\section{Performance of the bullfrog (Lithobathes catesbeianus) reared in a water recirculating system}

The survival rate was $97 \%$, and the mean daily weight gain in the different pens ranged from 0.79 to $2.40 \mathrm{~g}$. The mean values per weight range can be seen in Table 2 , as well as the data of mean weight and apparent feed conversion ratio.

A quite satisfactory performance of animals subjected to the water recirculating system was observed during the experiment. The weight gain reached was the expected for Lithobates castebeianus, with different ranges of live weight, considering the mean temperature observed in the water, once animals were submitted to the wet rearing system, remaining in the water. The mean water temperature was $22.8^{\circ} \mathrm{C}$ with minimum of $21^{\circ} \mathrm{C}$ and maximum of $25^{\circ} \mathrm{C}$. The daily weight gain in the different lots of frogs varied from 0.79 to $2.40 \mathrm{~g}$. The mean values per weight range and data of mean weight and apparent feed conversion ratio are listed in Table 2.

Oliveira et al. (2009) evaluated the performance of frogs with a mean initial weight of 33.8 grams in rearing wet system, with mean water temperature set at $27^{\circ} \mathrm{C}$ and fed with automatic feed dispensers. The growth of frogs up to 232.96 grams live weight was monitored and an apparent feed conversion ratio of 1.37:1 was registered. Regarding the weight range of frogs in pens 5 and 6 of the present study, whose initial weight was 65.95 and 110.84, and a final weight of 123.92 and 155 grams, the feed conversion ratio was higher than that found by the above cited authors, respectively, 1.07: 1 and 1.1: 1; this is despite the negative factor relative to the mean water temperature, i.e., during the experiment, the mean temperature was $22.8^{\circ} \mathrm{C}$. Braga and Lima (2001) verified the values of the feed conversion ratio between 1.40: 1 and 1.46: 1 , with temperatures between 20 and $30^{\circ} \mathrm{C}$, for 35 days of the study, and for frogs with an initial mean weight of 37.5 grams and final mean weight of 83.5 grams. The worst conversion in this study was verified for the frogs from pen 4 , which at the beginning of monitoring had a mean weight of 335.70 grams a weight above the standard of animals for slaughter.

The mean daily weight gain varied from 0.79 to 2.40 grams. Stands out the results of animals that at the onset of monitoring were within the weight range of animals of growing and fattening phases, thus commercially considered as animals for slaughter, with values of daily weight gain between 0.79 and 1.41 (pens 2, 5 and 6). Braga and Lima (2001) reached values of mean daily weight gain of $0.92 \mathrm{~g}$ at $20^{\circ} \mathrm{C} ; 1.46 \mathrm{~g}$ at $25^{\circ} \mathrm{C}$; and $1.40 \mathrm{~g}$ at $30^{\circ} \mathrm{C}$. Sousa et al. (2010) studied the performance of bullfrogs stocked in cages installed in tilapia ponds and fed with automatic dispensers for 60 days in the winter under a mean temperature of $18.1^{\circ} \mathrm{C}$. Frogs presented an initial mean weight of about 105 grams, and by the end of the experiment reached a mean weight between 129 and 139 grams, with daily weight gain of 0.42 and 0.58 grams, respectively - values lower than those found in this study. From March 1997 to February 2001, Lima, Casali and Agostinho (2003) monitored three commercial frog farms that adopted the "amphifarm" system. They observed values of daily weight gain between 0.4 and 2.5 grams, averaging 1.5 grams - similar to our results for animals within the weight range of growing and fattening animals (pens 2, 5 and 6).

Table 2: Results obtained during the experiment per pen, for mean weight, daily weight gain, and apparent feed conversion ratio.

\begin{tabular}{cccc}
\hline Pens & Mean weight (g) & Weight gain (g) /day & Apparent Feed Conversion Ratio (FCR) \\
\hline 1 & $391.24 \pm 65.38$ & 1.95 & $2.15: 1$ \\
2 & $252.37 \pm 46.73$ & 0.87 & $3.78: 1$ \\
3 & $342.80 \pm 55.10$ & 2.40 & $1.54: 1$ \\
4 & $367.98 \pm 67.68$ & 0.79 & $6.6: 1$ \\
5 & $123.92 \pm 45.34$ & 1.41 & $1.07: 1$ \\
6 & $155.91 \pm 56.35$ & 1.10 & $1.1: 1$ \\
\hline
\end{tabular}


The higher survival percentage was strong evidence that the system provided the comfort necessary to frogs to present a positive performance. The monitoring started with 362 and ended with 351 frogs, i.e., the survival rate was 97\%. Lima, Casali and Agostinho (2003) observed in the three commercial frog farms with the "amphifarm" system, mortality rates were from 0.5 to $39.5 \%$, with an average of $12 \%$, higher than found in the present study. Braga and Lima (2001) registered values from 10 to $14 \%$ in experimental pens based on the "amphifarm" system, and Mello (2001) verified 37.4\% in a wet system.

Table 3 presents the mean values and standard deviations of $\mathrm{pH}$, temperature, total ammonia and $\mathrm{NH}_{3}$ obtained at the three sampling points: central collector box, anaerobic biofilter outlet, and aerobic biofilter outlet.

\section{Results of daily monitoring the $\mathrm{pH}$, temperature, total ammonia and non-ionisable ammonia $\left(\mathrm{NH}_{3}\right)$}

The mean temperature of $22.8^{\circ} \mathrm{C}$ during the experiment was considered suboptimal for growing and fattening frogs, in agreement with Castro et al. (2014) who that showed the values of water temperature observed during the experiment $\left(16.4\right.$ to $20.8^{\circ} \mathrm{C}$ ) were under the recommended ones for the production of this species. Figueiredo et al. (1999) stated optimum values as those between 27.6 and $30.1{ }^{\circ} \mathrm{C}$. Braga and Lima (2001) observed better performances between 25 and $30^{\circ} \mathrm{C}$.

During the study, the water taken from the central collector box and from the anaerobic biofilter outlet reached values of total ammonia unfit for aquaculture. The ammonia was oxidised by chemoautotrophic bacteria in the aerobic biofilter, and values remained within compliant standards for the maintenance of frogs.

No significant differences were observed in $\mathrm{pH}$ values of the three monitoring points and between different periods. Values were within the ideal range for aquaculture species, as observed by Ferreira (2003), Hayashi (2004), Sipauba-Tavares, Morais and De Stéfani (2008), Borges, Amaral and De Stéfani (2012). The pH values also complied with the need for bacteria in the filtration process. The different groups of bacteria can present an optimum range of $\mathrm{pH}$ with different values, but most of them cannot tolerate $\mathrm{pH}$ above 9.5 or below 4.0. The optimum $\mathrm{pH}$ range for bacteria growth is between 6.5 and 7.5 (Metcalf; Eddy, 1981)

Table 3 also shows the values found for total ammonia and non-ionisable ammonia $\left(\mathrm{NH}_{3}\right)$ throughout the experiment at the three sampling points. Ferreira (2003) reported desirable values of $\mathrm{NH}_{3}$ and those that caused no apparent damage to Lithobates catesbeianus in captivity were, respectively, $0.5 \mathrm{mg} / \mathrm{L}$ and $0.7 \mathrm{mg} / \mathrm{L}$. Lima and Agostinho (1992) mentioned the tolerance limit of total ammonia at different stages of bull frog development has not been defined. In a study on tadpole storage densities, these authors attributed the increase in density to increased total rate of total ammonia in the water, and high mortality was observed at $1.23 \mathrm{mg} / \mathrm{L}$, when two tadpoles were stored per litre.

In the Resolution of CONAMA 357 (Brasil, 2005) water is considered suitable for aquaculture when it has total ammonia values of up to $3.7 \mathrm{mg} / \mathrm{L}$ in $\mathrm{pH}<7.5$. During this experiment, the water taken from the central collector box and from the anaerobic biofilter outlet reached values of total ammonia unfit for aquaculture. In the aerobic biofilter, the ammonia had been oxidised by chemoautotrophic bacteria, Nitrosomonas and Nitrobacter, and water had values suitable for aquaculture.

\section{Removal of organic load and total phosphorus}

The mean values of BOD are shown in Table 4 and Figure 2 and total phosphorus in Table 4 of samples collected at the central collector box, anaerobic biofilter outlet, and aerobic biofilter outlet. During the experimental period, the organic matter removal reached the mean value of $66 \%$ and the mean percentage of phosphorus removal was 21.5. When the result of the analysis was considered after 40 days, i.e. on the last day of experiment, the organic matter removal achieved $87 \%$ and the phosphorus removal, $39 \%$ (Figure 3).

Table 3: Mean values and standard deviation of $\mathrm{pH}$, temperature, total ammonia and $\mathrm{NH}_{3}$ of the water from the three sampling points during the experimental period.

\begin{tabular}{ccccc}
\hline Parameters & $\mathrm{pH}$ & $\mathrm{T}^{\circ}$ & Total ammonia $(\mathrm{mg} / \mathrm{L})$ & $\mathrm{NH}_{3}(\mathrm{mg} / \mathrm{L})$ \\
\hline Central collector box & $6.81 \mathrm{a} \pm 0.16$ & $22.07 \mathrm{a} \pm 1.25$ & $3.26 \mathrm{a} \pm 1.80$ & $0.012 \mathrm{a} \pm 0.008$ \\
Anaerobic biofilter outlet & $6.81 \mathrm{a} \pm 0.13$ & $22.18 \mathrm{a} \pm 1.36$ & $4.01 \mathrm{a} \pm 1.52$ & $0.014 \mathrm{a} \pm 0.006$ \\
Aerobic biofilter outlet & $6.82 \mathrm{a} \pm 0.16$ & $22.78 \mathrm{a} \pm 1.70$ & $1.04 \mathrm{~b} \pm 1.83$ & $0.004 \mathrm{~b} \pm 0.008$ \\
\hline
\end{tabular}

Values followed by the same letter in the column are not significantly different $(P>0.05)$ by $t$-test. 
Table 4: Mean values of results of Biochemical Oxygen Demand (BOD) and total phosphorus of water samples from the three sampling points.

\begin{tabular}{ccc}
\hline & $\mathrm{BOD}\left(\mathrm{mgO}_{2} / \mathrm{L}\right)$ & Total phosphorus $(\mathrm{mg} / \mathrm{L})$ \\
\hline Central collector box & $79.08 \mathrm{a}$ & $3.80 \mathrm{a}$ \\
Anaerobic biofilter outlet & $33.78 \mathrm{~b}$ & $2.98 \mathrm{~b}$ \\
Aerobic biofilter outlet & $27.26 \mathrm{~b}$ & $3.04 \mathrm{~b}$ \\
\hline
\end{tabular}

Values followed by the same letter in the column are not significantly different $(P>0.05)$ by Wilcoson test.

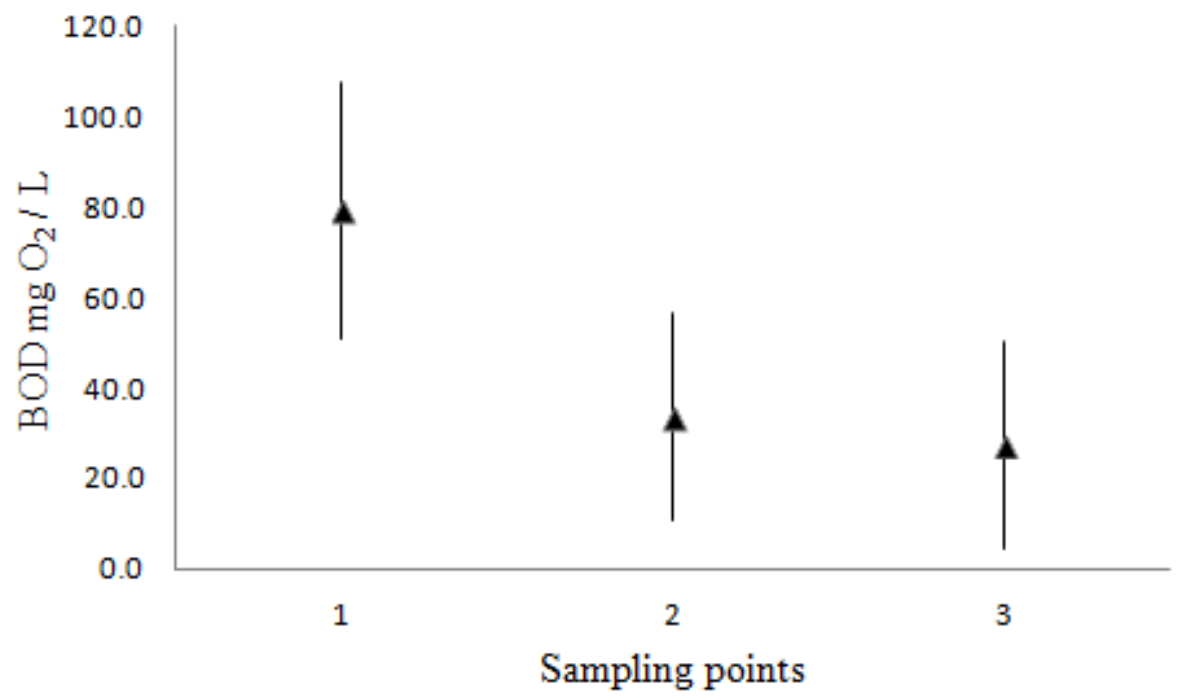

Figure 2: Scatter plot of mean values of Biochemical Oxygen Demand (BOD) of the three sampling points with confidence intervals during the experimental period.

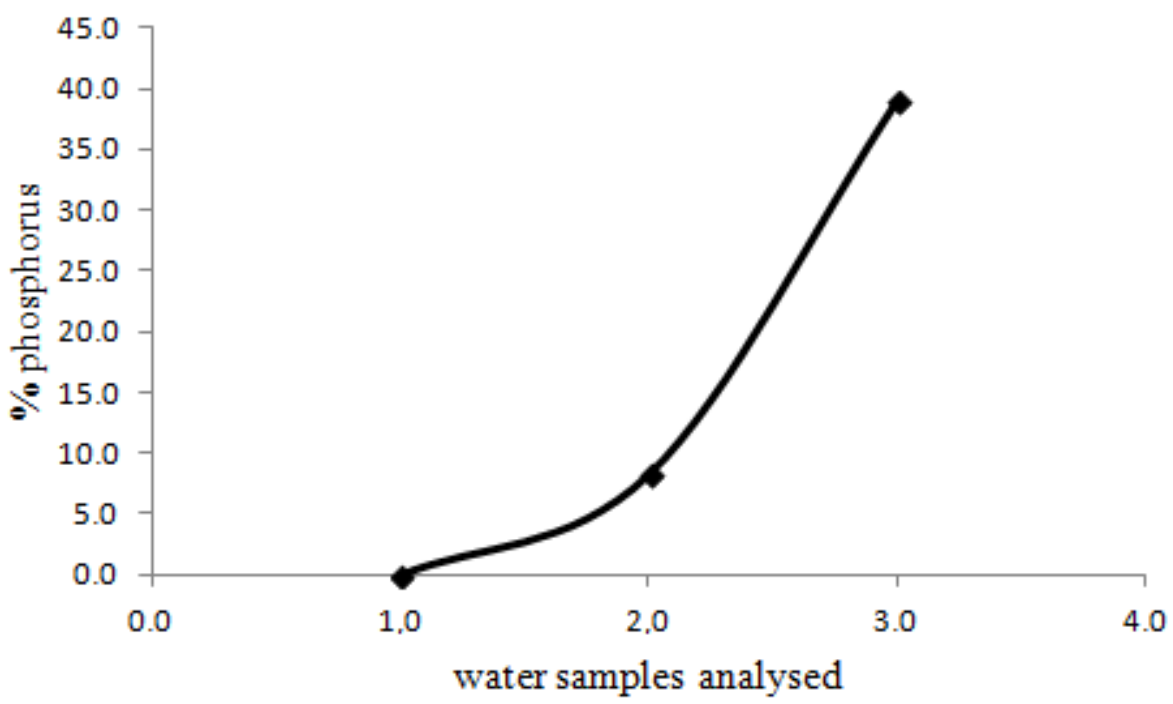

Figure 3: Percentage removal of phosphorus by the anaerobic filter in the three water samples analysed during the experimental period. 
As for the optimal temperature for growth of bacteria in the anaerobic biofilter, Van Haandel and Lettinga (1994) mentioned that temperatures between $30{ }^{\circ} \mathrm{C}$ and $40{ }^{\circ} \mathrm{C}$ promoted a maximum rate of anaerobic digestion; but for temperatures below $30{ }^{\circ} \mathrm{C}$, the anaerobic digestion rate decreased at a rate of $1 \%$ per $10{ }^{\circ} \mathrm{C}$. At low temperatures, the fraction of organic solids that can be metabolised in the process is reduced. The anaerobic digestion is possible in low temperatures, but its effectiveness and the digestion rate are reduced. The experimental period took place between August and September, with temperatures below $30^{\circ} \mathrm{C}$; in this way, it can be inferred that in summer, the filter will probably present a higher efficiency.

The use of an anaerobic biofilter for domestic wastewater treatment was examined by Van Haandel et al. (2006) who attained between 70 and $80 \%$ removal of BOD, which is close to that obtained in the analysis on the fortieth and final day of the study (87\%).

The phosphorus removal efficiency by the filtration system was low (Table 4). Based on estimates of improved efficiency of the filtering system over time in a period of about six months, after the initial operation, it will be possible to achieve greater removal percentages.

The results obtained in the analysis of BOD showed that it was possible to remove approximately $87 \%$ of the organic load. Regarding phosphorus, it was possible to remove up to $39 \%$, which is lower than expected for anaerobic systems. The filtration in the anaerobic system was responsible for the removal of a great part of organic matter, and the aerobic system could reduce the percentage of toxic ammonia to negligible levels.

\section{CONCLUSIONS}

A satisfactory performance of animals subjected to the water recirculating system was observed during the experiment.

The combination of filtration systems (aerobic and anaerobic biofilters) was essential for the removal of organic matter and toxic ammonia from the water.

The recirculating system proposed in this study contributes to environmental preservation, and enables the rearing of frogs under low water availability.

\section{REFERENCES}

ASSOCIAÇÃO BRASILEIRA DE NORMAS TÉCNICAS-ABNT. NBR

7229: Projeto, construção e operação de sistemas de tanques sépticos. Rio de Janeiro: ABNT, 1993.
ASSOCIAÇÃO BRASILEIRA DE NORMAS TÉCNICAS-ABNT. NBR 13969: Tanques sépticos - Unidades de tratamento complementar e disposição final dos efluentes líquidos Projeto, construção e operação. Rio de Janeiro: ABNT, 1997.

ASSOCIATION OF OFFICIAL ANALYTICAL CHEMISTS-AOAC. Official Methods of Analysis. 15.ed. Arlington, 1990. v.1, 684p.

BORGES, F. F.; AMARAL, L. A.; de STÉFANI, M. V. Characterization of effluents from bullfrog (Lithobates catesbeianus, Shaw, 1802) grow-out ponds. Acta Limnologica Brasiliensia, 24:160-166, 2012.

BRAGA, L. G. T.; LIMA, S. L. Influência da temperatura ambiente no desempenho da rã-touro, Rana catesbeiana. Revista Brasileira de Zootecnia, 30:1659-1663, 2001.

BRASIL. Resolução CONAMA n³57/2005. Dispõem sobre a classificação dos corpos de água e diretrizes ambientais para o seu enquadramento, bem como estabelece as condições e padrões de lançamento de efluentes e dá outras providências. Diário Oficial da União: 18/03/2005.

CARRARO, K. C. Ranicultura: um bom negócio que contribui para a saúde. Revista FAE, 11:111-118, 2008.

CASTRO, C. S. et al. Polyculture of frogs and tilapia in cages with high feeding frequency. Aquacultural Engineering, 61:43-48, 2014.

CYNAMON, S. E. Sistema não convencional de esgoto sanitário a custo reduzido para pequenas coletividades e áreas periféricas. Rio de Janeiro: Fundação Oswaldo Cruz, Escola Nacional Saúde Pública, 1986. 52p.

FERREIRA, C. M. A. Importância da água e sua utilização em ranários comerciais. Revista Panorama da Aquicultura, 13:15-17, 2003.

FIGUEIREDO, M. R. C. et al. Efeito da temperatura sobre o desempenho da rã-touro (Rana catesbeiana Shaw, 1802). Revista brasileira de Zootecnia, 28:661-667, 1999.

FLORES-NAVA, A. Bullfrog farming: comparison of inundated and semi-dry ongrowing methods. The Advocate, p.52$54,2000$.

HAYASHI, C. et al. Desenvolvimento de girinos de rã-touro (Rana catesbeiana Shaw, 1802) cultivados em diferentes densidades de estocagem em tanque-rede. Revista Brasileira de Zootecnia, 33:14-20, 2004.

INSTITUTO ESTADUAL DO AMBIENTE-INEA. Diretriz de Controle de Carga Orgânica Biodegradável em Efluentes Líquidos de Origem Sanitária, DZ-215.R-4, Aprovada pela deliberação CECA n 4886, 2007. 
LIMA, S. L.; AGOSTINHO, C. A. A tecnologia de criação de rãs. Viçosa-MG: UFV, 1992. 168p.

LIMA, S. L.; CASALI, A. P.; AGOSTINHO, C. A. Desempenho zootécnico e percentual de consumo de alimento de rã-touro (Rana catesbeiana) na fase de recria (pósmetamorfose) do sistema Anfigranja. Revista Brasileira de Zootecnia, 32:505-511, 2003.

MELLO, S. C. R. P. Sistema inundado de criação de rãs: Ensaios experimentais. Boletim Técnico do Instituto de Pesca, 31:26-33, 2001.

MERCANTE, C. T. J. et al. Bullfrog (Lithobates catesbeianus) farming system: Water quality and environmental changes. Acta Limnologica Brasiliensia, 26:9-17, 2014.

METCALF, L.; EDDY, P. H. Tratamiento y Depuración de las aguas residuales. 2.ed., Barcelona: Editorial Labor S.A., $1981.837 p$.

OLIVEIRA, F. A. et al. Manejo alimentar com dispensador automático na recria de rã-touro. Archivos de Zootecnia, 58:589-592, 2009.
SIPAÚBA-TAVARES, L. H.; MORAIS, J. C. L.; STÉFANI, M. V. de. Comportamento alimentar e qualidade de água em tanques de criação de girinos de rã-touro Lithobates catesbeianus. Acta Scientarium. Animal Science, 30:95101, 2008.

SOUSA, R. M. R. et al. Recria de rã-touro (Rana catesbeiana) em tanques rede alojados em viveiros de tilápia. Archivos de Zootecnia, 59:31-38, 2010.

TEIXEIRA, R. D.; MELLO, S. C. R. P.; SANTOS, C. A. M. L. dos. The world market for frogs legs. FAO/ Globefish Research Programme, 68:1-44, 2001

VAN HAANDEL, A.; LETTINGA, G. Tratamento anaeróbio de esgotos - um manual para regiões de clima quente. Campina Grande: Guerreiro e Catunda, 1994. 125p.

VAN HAANDEL, A. et al. Anaerobic reactor design concepts for treatment of domestic wastewater. Reviews in Environmental Sciences and Biotechnology, 5:21-38, 2006. 